\title{
Serological survey and risk factors associated with Toxoplasma gondii infection among HIV-infected pregnant women attending Abuja Tertiary Hospital, Nigeria
}

\author{
Maryam Muhammad Zakari ${ }^{1}$, Aliyu Yabagi Isah ${ }^{1}$, Richard Offiong ${ }^{1}$, Thairu Yunusa ${ }^{2}$, Idris Nasir \\ Abdullahi ${ }^{3}$
}

1. Department of Obstetrics and Gynecology, University of Abuja Teaching Hospital, Gwagwalada, Abuja, Nigeria

2. Department of Medical Microbiology and Parasitology, University of Abuja Teaching Hospital, Gwagwalada, Abuja, Nigeria

3. Department of Medical Laboratory Science, Faculty of Allied Health Sciences, Ahmadu Bello University, Zaria, Nigeria

Correspondence: Idris Nasir Abdullahi (inabdullahi@abu.edu.ng, eedris888@yahoo.com)

\section{Background}

\section{Abstract}

Toxoplasmosis in pregnancy could induce miscarriage, congenital anomalies in foetuses and encephalitis in HIV-infected people. Hence, there is a need to determine the prevalence of toxoplasmosis in HIV-infected pregnant women to inform clinicians about the significance of maternal toxoplasmosis in antenatal care.

Aim

This study aimed to determine the seroprevalence of Toxoplasma gondii infection, associated CD4+ T-cell profile and sociodemographic risk factors among pregnant women with or without HIV infection attending the University of Abuja Teaching Hospital, Abuja, Nigeria.

Methods

This hospital-based cross-sectional study involved blood samples collected from $160 \mathrm{HIV}$-infected and 160 HIV-seronegative pregnant women. These samples were analysed for anti-T. gondii (IgG and IgM) and CD4+ T-cell count using ELISA and flow cytometry, respectively. Sociodemographic variables of participants were collected using structured questionnaires.

Results

The overall seroprevalence of anti-T. gondii IgG and IgM was $28.8 \%$ and 3.8\%, respectively. The seroprevalence of anti-T. gondii IgG and $\operatorname{IgM}$ was $29.4 \%$ and $4.4 \%$, respectively, among HIV-seropositive pregnant women and $28.1 \%$ and $3.1 \%$, respectively, among HIVseronegative women. There was no significant association between the seroprevalence of anti-T. gondii-IgG and anti-T. gondii-IgM with age, gestational age, education level, parity or place of residence of $\mathrm{HIV}$-infected pregnant women $(\mathrm{P}>0.05)$. However, there was significant association between the seroprevalence of anti-T. gondii- $\operatorname{IgG}(\mathrm{P}=0.03)$ and anti- $\mathrm{T}$. gondii-IgM $(\mathrm{P}=0.01)$ with education level. CD4+ T-cell count varied significantly between HIV-infected and HIV-uninfected pregnant women $(\mathrm{P}=0.035)$.

Conclusion

In this study, the seroprevalence of anti-T. gondii IgG and IgM did not differ in HIV-seropositive or HIV-seronegative pregnant women. However, women with primary T. gondii and HIV coinfection had lower CD4+ T-cell count than those with toxoplasmosis monoinfection.

Key Words

Toxoplasmosis, HIV coinfection, congenital anomaly, cellular immunity, sero-survey

\section{Introduction}

Toxoplasma gondii, the aetiological agent of toxoplasmosis, is a zoonotic parasite that has latently affected $33.8 \%$ of pregnant women worldwide in the last three decades ${ }^{1}$. The ubiquitous obligate intracellular coccidian protozoan infects a wide variety of domesticated animals (such as cats and dogs), birds and humans ${ }^{1}$. Clinically, toxoplasmosis is an opportunistic parasitic infection in immunocompromised and immunosuppressed people that has led to serious public health morbidities including physical and/or psychological sequelae for people living with $\mathrm{HIV} / \mathrm{AIDS}^{2}$. However, in the vast majority of immunocompetent people, T. gondii infection is latent, characterised by the persistence of the parasites in the brain, skeletal muscles and heart without causing clinical diseases ${ }^{3}$.

In chronically infected people who develop cell-mediated immunodeficiency, symptomatic toxoplasmosis is more likely to occur as a result of reactivated infection, especially due to $\mathrm{CD}^{+} \mathrm{T}$ lymphopenia ${ }^{4}$ below 100 cells $/ \mathrm{mm}^{3}$. Consequently, toxoplasmosis among people living with $\mathrm{HIV} / \mathrm{AIDS}$ mainly manifests as toxoplasma encephalitis ${ }^{5}$. In pregnant women, toxoplasmosis has been implicated in prenatal and congenital transmission, causing miscarriage or congenitally acquired disorders that primarily affect the central nervous system of neonates ${ }^{6}$. Nigeria has one of the highest HIV prevalences, with 1.4\% among adults aged 15-49 years in 2019. HIV prevalence was highest among females aged between 35 and 39 years ${ }^{7}$. According to the recent Nigeria National AIDS Indicator Survey, Abuja was 15 th out of 37 states and the capital for highest HIV prevalence. People living in the Abuja suburbs had relatively higher rates of HIV infection compared with those residing in the main Abuja city. Furthermore, higher prevalence was reported among women within the reproductive age group ${ }^{7}$. An overall toxoplasmosis prevalence of $31.5 \%$ was reported in Abuja ${ }^{8}$ with similar immunoglobulin M and G (IgM and 
$\operatorname{Ig} G)$ seropositivity, as previously reported in other Nigerian studies ${ }^{9,10}$. When a pregnant woman contracts $T$. gondii infection in the first trimester which is allowed to be untreated, the risk of miscarriage is significantly high ${ }^{11}$. However, in the third trimester, untreated T. gondii infection increases the risk of toxoplasma-induced congenital anomalies in neonates ${ }^{11}$. There is a paucity of studies in Nigeria that focus on simultaneous investigation of toxoplasmosis and its impact of $\mathrm{CD}^{+} \mathrm{T}$ cellular immunity in pregnant women living with HIV/AIDS in comparison to those who are HIV seronegative. Hence, this study sought to determine the seroprevalence of anti- $T$. gondii, associated $\mathrm{CD}^{+}{ }^{+} \mathrm{T}$-cell profile and sociodemographic risk factors among pregnant women with or without HIV infection attending the University of Abuja Teaching Hospital (UATH) in Nigeria.

\section{Methods}

\section{Study design}

This was a hospital-based cross-sectional study.

\section{Study area}

This study was conducted between 2 February 2017 and 28 January 2018 at the Department of Obstetrics and Gynecology and Immunology, UATH, Abuja. The hospital provides healthcare services to the inhabitants of Abuja and neighbouring states including Niger, Kaduna, Kogi and Nasarawa states. The hospital has an average of 3000 deliveries annually. The laboratory investigations were carried out at the Immunology Laboratory of UATH.

\section{Study population}

This included consecutively enrolled $160 \mathrm{HIV}$-seropositive and $160 \mathrm{HIV}$-seronegative pregnant women who attended antenatal clinics at UATH. All participants were retested for HIV serostatus using the World Health Organization (WHO) algorithm by Uni-Gold Recombigen HIV-1/2 (Trinity Biotech, Wicklow, Ireland) and Determine ${ }^{\mathrm{TM}}$ (Alere, Auckland, New Zealand) proprietary reagents. There were no new HIV-seropositive cases and all the seropositive subjects were on antiretroviral therapy.

\section{Sample size determination}

The minimum sample size for this study was determined from the prevalence of $29.1 \%$ anti-toxoplasma IgG in pregnant women $^{9}$ as 317 . In total, 320 consenting participants were recruited.

\section{Ethical considerations}

The ethical approval for this study was obtained from the Research Ethics Committee of the University of Abuja Teaching Hospital (Approval Number: FCT/UATH/ HREC/PR/416). Written informed consent was sought from all participants before enrolment into the study. For participants who were not literate and those who may not have understood the medium of communicating the study, translation was done using their local dialects before they consented by nodding their heads, signing the consent form or making a thumb-print on the signature area. All data were treated with utmost confidentiality. The protocols of this study were conducted in accordance with the Helsinki declaration of 1973 (revised in 2000) ${ }^{12}$.

\section{Sample collection and processing}

The purpose of this work was explained to the subjects before their consent to participate was sought. Intervieweradministered, structured questionnaires were used as a study tool. The questions outlined in the data forms were explained to the subjects and then completed with the required information which included bio-demographic data. Five millilitres of blood was aseptically collected from each participant via venepuncture.

Three millilitres were dispensed into a plain (no-anticoagulant) container, while the remaining $2 \mathrm{ml}$ was dispensed into an EDTA anticoagulated bottle which was used for $\mathrm{CD}^{+}$ T-cell counts (within $1 \mathrm{~h}$ of collection). The blood in the plain container was allowed to clot and retracted. The serum was harvested after separation from the red cells by centrifugation at $10,000 \mathrm{~g}$ for $10 \mathrm{~min}$. The serum samples were appropriately labelled and refrigerated $\left(2-8{ }^{\circ} \mathrm{C}\right)$ until ELISA analysis was done within $24 \mathrm{~h}$ of collection.

\section{Laboratory analysis}

\section{Toxoplasma gondii IgG and IgM ELISA}

The samples were analysed for the presence of $\mathrm{IgG} / \mathrm{IgM}$ class antibodies to T. gondii by ELISA using Toxo IgG/Toxo IgM ELISA kits (Fortress Diagnostics Limited, Antrim, UK) which are qualitative and quantitative immunoassays for the detection of human antibodies in serum or plasma directed against $T$. gondii. The interpretation of tests and results was carried out based on the manufacturer's instructions.

\section{Flow cytometry of $C D 4^{+}$T lymphocytes}

Based on the manufacturer's instructions, the $\mathrm{CD}^{+}$cell counts in the whole blood were analysed using a Partec ${ }^{\mathrm{TM}}$ CyFlow Analyzer (Sysmex, Norderstedt, Germany) Model SL3. This device uses the principle of light scattering (based on dissimilarity in cell size or granularity) and the fluorescence of cells following staining with monoclonal antibodies to markers on the cell surface bound to fluorescent dyes. Flow cytometry data were analysed using FlowJo version 7.6.5 software (Becton Dickinson, Franklin Lakes, NJ, USA) and cell populations of interest were then gated after identification. The generated percentages were multiplied by the total number of lymphocytes in the haemogram to derive absolute values for circulating lymphocytes. Absolute $\mathrm{CD}^{+}$cell counts were subsequently analysed using a single-

\section{platform technique.}

\section{Statistical analysis}

The data were analysed using Statistical Package for Social Sciences (SPSS) software version 20.0 (IBM, CA, USA). Chisquare was used to determine significant association between the prevalence of anti-T. gondii and sociodemographic variables of participants. The $t$-test was used to determine the difference between $\mathrm{CD}^{+}{ }^{+} \mathrm{T}$-cell counts between the two groups of participants. One-way ANOVA with Tukey's test was used to determine differences in $\mathrm{CD}^{+}$T-cell count across the three gestational groups of subjects with HIV/T. gondii coinfection and T. gondii monoinfection. $P$-values $\leq 0.05$ at confidence interval (CI) of $95 \%$ were considered significant.

\section{Results}

The overall seroprevalence of anti-T. gondii IgG and IgM was $28.8 \%$ and $3.8 \%$, respectively. Of the $160 \mathrm{HIV}$ seropositive and $160 \mathrm{HIV}$-seronegative pregnant women tested, the seroprevalence of anti-toxoplasma $\operatorname{IgG}$ and $\operatorname{IgM}$ was $29.4 \%$ and $4.4 \%$, respectively, among HIV-seropositive pregnant women and $28.1 \%$ and $3.1 \%$, respectively, among HIV-seronegative women (Table 1). The seroprevalence of anti-T. gondii IgG and IgM among HIV-seropositive pregnant women was highest among those aged 20-39 years, with 45 $(95.7 \%)$ and $7(100.0 \%)$ seropositive cases, respectively, of IgG and IgM.

Those living in urban areas had more cases of anti-T. gondii $\mathrm{IgG}$ and IgM antibodies than their rural counterparts $(91.5 \%$ and $4 \%$ versus $100.0 \%$ and $0.0 \%$, respectively) (Table 2 ). The seroprevalence of anti-T. gondii $\operatorname{IgG}$ and IgM was highest 
among HIV-seropositive pregnant women with tertiary education (20 [42.6\%] and 5 [71.4\%], respectively). Pregnant women at their third trimester $(23[48.9 \%]$ and $3[42.9 \%])$ had the highest prevalence of anti-T. gondii IgG and IgM than those at their first and second trimester (19.2\% versus $14.2 \%$ and $31.9 \%$ versus $42.9 \%$, respectively).

Table 1. Seroprevalence of Toxoplasma gondii antibodies among pregnant women $(n=320)$

\begin{tabular}{|l|l|l|l|l|}
\hline HIV status & $\begin{array}{l}\text { IgG positive } \\
(\%)\end{array}$ & P-value & $\begin{array}{l}\text { IgM } \\
\text { positive } \\
(\%)\end{array}$ & P-value \\
\hline $\begin{array}{l}\text { HIV-positive } \\
(\mathrm{n}=160)\end{array}$ & $47(29.4)$ & 0.5315 & $7(4.4)$ & 0.5416 \\
\hline $\begin{array}{l}\text { HIV- } \\
\text { negative }(\mathrm{n} \\
=160)\end{array}$ & $45(28.1)$ & & $5(3.1)$ & \\
\hline Total & $92(28.8)$ & & $12(3.8)$ & \\
\hline
\end{tabular}

HIV-uninfected pregnant women with parity of $1-4$ had the highest anti-T. gondii $\operatorname{IgG}(62.2 \%)$ when compared with the nulliparous $(22.2 \%)$ and those with parity $\geq 5(15.6 \%)$. Similarly, HIV-uninfected pregnant women with parity of 1-4 had the highest anti-T. gondii $\operatorname{IgM}(60.0 \%)$ when compared with the nulliparous $(20.0 \%)$ and those with parity $\geq 5(20.0 \%)$ (Table 2$)$. There was no significant association between the seroprevalence of anti-T. gondii-IgG and -IgM with age, gestational age, educational level, parity and place of residence of $\mathrm{HIV}$-infected pregnant women $(P>0.005)$ (Table 2).
The seroprevalence of anti-T. gondii $\operatorname{IgG}$ and $\operatorname{IgM}$ was highest among HIV-seronegative pregnant women between 20 and 39 years $(40[88.9 \%]$ and 5 [100.0\%], respectively). Those living in urban areas had more cases of anti- $T$. gondii IgG antibodies than their rural counterparts $(84.4 \%$ versus $80.0 \%$ ) (Table 3). In contrast, the seroprevalence of anti-T. gondii $\mathrm{IgM}$ was relatively lower among those residing within urban areas compared with rural residents $(15.6 \%$ versus $20.0 \%$ ) (Table 3).

The seroprevalence of anti-T. gondii IgG and IgM was highest among HIV-seronegative pregnant women with tertiary education (33 [73.3\%] and 5 [100.0\%], respectively). Pregnant women at their third trimester had a higher prevalence of anti-T. gondii IgG and IgM (23 [51.1\%] and $3[60.0 \%]$, respectively) than those at their first and second trimester $(13.3 \%$ versus $35.6 \%$ and $20.0 \%$ versus $20.0 \%$, respectively).

Nulliparous HIV-infected pregnant women had the least anti-T. gondii $\operatorname{IgG}(12.8 \%)$ when compared with those with parity of $1-4(46.8 \%)$ and $\geq 5$ parity (40.4\%). However, HIV-infected pregnant women with parity of $1-4$ had the highest anti-T. gondii IgM (57.1\%) when compared with the nulliparous $(14.3 \%)$ and those with parity $\geq 5(28.6 \%)$ (Table 3). There was significant association between the seroprevalence of anti-T. gondii-IgG and -IgM with education level but only anti-T. gondii-IgM was significantly associated with place of residence $(P=0.01)$. However, there was no association between age and parity of HIV-seronegative pregnant women $(P>0.05)$ (Table 3).

HIV-infected pregnant women without anti-T. gondii IgM

Table 2. Seroprevalence of anti-Toxoplasma gondii IgG and IgM by sociodemographic variables of HIV-infected pregnant women

\begin{tabular}{|c|c|c|c|c|c|c|}
\hline \multirow[t]{2}{*}{ Variable } & \multicolumn{3}{|l|}{$\lg G$} & \multicolumn{3}{|l|}{$\lg M$} \\
\hline & Positive (\%) & Negative (\%) & $P$-value & Positive (\%) & Negative (\%) & $P$-value \\
\hline \multicolumn{7}{|c|}{ Age (years) } \\
\hline$\leq 19$ & $0(0.0)$ & $0(0.0)$ & & $5(3.3)$ & $5(4.4)$ & \\
\hline 20-39 & $45(95.7)$ & $98(86.7)$ & 0.778 & $7(100.0)$ & $136(88.9)$ & 0.804 \\
\hline$\geq 40$ & $2(4.3)$ & $10(8.9)$ & & $0(0.0)$ & $12(7.8)$ & \\
\hline \multicolumn{7}{|c|}{ Place of residence } \\
\hline Urban & $43(91.5)$ & $84(74.3)$ & 0.360 & $7(100.0)$ & $120(78.4)$ & 0.790 \\
\hline Rural & $4(8.5)$ & $29(25.7)$ & & $0(0.0)$ & $33(21.6)$ & \\
\hline \multicolumn{7}{|c|}{ Educational status } \\
\hline $\begin{array}{l}\text { No formal } \\
\text { education }\end{array}$ & $3(6.4)$ & $25(22.1)$ & & $0(0.0)$ & $28(18.3)$ & \\
\hline Primary & $14(29.8)$ & $9(8.0)$ & 0.061 & $2(28.6)$ & $21(13.7)$ & 0.248 \\
\hline Secondary & $10(21.3)$ & $38(33.6)$ & & $0(0.0)$ & $48(31.4)$ & \\
\hline Tertiary & $20(42.6)$ & $41(36.3)$ & & $5(71.4)$ & $56(36.6)$ & \\
\hline \multicolumn{7}{|l|}{ Parity } \\
\hline Nulliparous & $6(12.8)$ & $50(44.3)$ & & $1(14.3)$ & $55(35.9)$ & \\
\hline Parity 1-4 & $22(46.8)$ & $32(28.3)$ & 0.642 & $4(57.1)$ & $50(32.7)$ & 0.919 \\
\hline Parity $\geq 5$ & $19(40.4)$ & $31(27.4)$ & & $2(28.6)$ & $48(31.4)$ & \\
\hline \multicolumn{7}{|c|}{ Gestational age } \\
\hline 1st trimester & $9(19.2)$ & $25(22.1)$ & & $1(14.2)$ & $33(21.6)$ & \\
\hline 2nd trimester & $15(31.9)$ & $38(33.6)$ & 0.606 & $3(42.9)$ & $50(32.7)$ & 0.119 \\
\hline 3rd trimester & $23(48.9)$ & $50(44.3)$ & & $3(42.9)$ & $70(45.7)$ & \\
\hline
\end{tabular}

*Significant difference determined by chi-square test. 
Table 3. Seroprevalence of anti-Toxoplasma gondii IgG and IgM by sociodemographic variables of HIV-seronegative pregnant women.

\begin{tabular}{|c|c|c|c|c|c|c|}
\hline \multirow[t]{2}{*}{ Variable } & \multicolumn{2}{|l|}{$\lg \mathbf{G}$} & \multirow[t]{2}{*}{$P$-value } & \multicolumn{2}{|l|}{$\lg M$} & \multirow[t]{2}{*}{$P$-value } \\
\hline & Positive (\%) & Negative (\%) & & Positive (\%) & Negative (\%) & \\
\hline \multicolumn{7}{|l|}{ Age (years) } \\
\hline$\leq 19$ & $0(0.0)$ & $1(0.9)$ & & $0(0.0)$ & $1(0.6)$ & \\
\hline $20-39$ & $40(88.9)$ & $111(96.5)$ & 0.333 & $5(100.0)$ & $146(94.2)$ & 0.554 \\
\hline$\geq 40$ & $5(11.1)$ & $3(2.6)$ & & $0(0.0)$ & $8(5.2)$ & \\
\hline \multicolumn{7}{|l|}{$\begin{array}{l}\text { Place of resi- } \\
\text { dence }\end{array}$} \\
\hline Urban & $38(84.4)$ & $114(99.1)$ & & $4(80.0)$ & $148(95.5)$ & \\
\hline Rural & $7(15.6)$ & $1(0.9)$ & 0.250 & $1(20.0)$ & $7(4.5)$ & $0.010^{*}$ \\
\hline \multicolumn{7}{|l|}{$\begin{array}{l}\text { Educational } \\
\text { status }\end{array}$} \\
\hline $\begin{array}{c}\text { No formal educa- } \\
\text { tion }\end{array}$ & $0(0.0)$ & $7(6.1)$ & & $0(0.0)$ & $7(4.5)$ & \\
\hline Primary & $4(8.9)$ & $30(26.1)$ & 0.033 & $0(0.0)$ & $34(22.0)$ & 0.010 \\
\hline Secondary & $8(17.8)$ & $50(43.5)$ & & $0(0.0)$ & $58(37.4)$ & \\
\hline Tertiary & $33(73.3)$ & $28(24.3)$ & & $5(100.0)$ & $56(36.1)$ & \\
\hline Total & $45(100.0)$ & $115(100.0)$ & & $5(100.0)$ & $155(100.0)$ & \\
\hline \multicolumn{7}{|l|}{ Parity } \\
\hline Nulliparous & $10(22.2)$ & $9(7.8)$ & & $1(20.0)$ & $18(11.6)$ & \\
\hline Parity 1-4 & $28(62.2)$ & $56(48.7)$ & 0.125 & $3(60.0)$ & $81(52.3)$ & 0.073 \\
\hline Parity $\geq 5$ & $7(15.6)$ & $50(43.5)$ & & $1(20.0)$ & $56(36.1)$ & \\
\hline \multicolumn{7}{|l|}{ Gestational age } \\
\hline 1st trimester & $6(13.3)$ & $20(17.4)$ & & $1(20.0)$ & $25(16.1)$ & \\
\hline 2nd trimester & $16(35.6)$ & $44(38.3)$ & 0.544 & $1(20.0)$ & $59(38.1)$ & 0.999 \\
\hline 3rd trimester & $23(51.1)$ & $51(44.3)$ & & $3(60.0)$ & $71(45.8)$ & \\
\hline
\end{tabular}

*Significant difference determined by chi-square test

Table 4. Toxoplasma gondii serological status and $\mathrm{CD}^{+} \mathrm{T}$-cell counts among HIV-infected pregnant women.

\begin{tabular}{|c|c|c|c|}
\hline Sero-status & Subjects (n) & Mean士SD CD4 ${ }^{+}$ & $P$-value \\
\hline $\begin{array}{l}\text { (a) HIV+ and } \\
\text { Toxo lgM+ }\end{array}$ & 7 & $324 \pm 23.4$ & \\
\hline $\begin{array}{l}\text { (b) HIV+ and } \\
\text { Toxo IgM- }\end{array}$ & 153 & $431 \pm 55.1$ & \\
\hline Total & 160 & $420 \pm 52.2$ & 0.035 \\
\hline $\begin{array}{l}\text { (a) HIV+ and } \\
\text { Toxo lgG+ }\end{array}$ & 47 & $340 \pm 31.9$ & \\
\hline (b) HIV+ and lgG- & 113 & $372 \pm 45.2$ & \\
\hline Total & 160 & $330 \pm 33.5$ & 0.075 \\
\hline
\end{tabular}

*Significant difference determined by $t$-test

had significantly higher $\mathrm{CD} 4^{+} \mathrm{T}$-cell count $(431 \pm 55.1$ cells / $\mathrm{mm}^{3}$, mean $\left.\pm \mathrm{SD}\right)$ than those who were anti-T. gondii IgM seropositive $\left(324 \pm 23.4\right.$ cells $\left./ \mathrm{mm}^{3} ; P=0.035\right)$. However, $\mathrm{HIV}$-infected pregnant women without anti-T. gondii IgG did not have a significantly different T-cell count (372 \pm 45.2 cells $/ \mathrm{mm}^{3}$ ) compared with those who were anti-T. gondii IgG seropositive $\left(340 \pm 31.9\right.$ cells $\left./ \mathrm{mm}^{3} ; P=0.075\right)$ (Table 4).Based on T. gondii IgG serostatus, it was observed that HIV-infected pregnant women at their third trimester had the lowest mean $\mathrm{CD}^{+}$T-cell count $\left(284 \pm 18.9\right.$ cells $\left./ \mathrm{mm}^{3}\right)$, followed by those in their second trimester $\left(323 \pm 24.2\right.$ cells $\left./ \mathrm{mm}^{3}\right)$, then those in their first trimester $\left(358 \pm 28.6\right.$ cells $\left./ \mathrm{mm}^{3}\right)$. However, based on their T. gondii IgM serostatus, it was observed that HIV-infected pregnant women at their first trimester had the lowest mean $\mathrm{CD}^{+}$T-cell count $\left(399 \pm 0\right.$ cells $\left./ \mathrm{mm}^{3}\right)$, followed by those in their third trimester ( $411 \pm 38.5$ cells/ $\left.\mathrm{mm}^{3}\right)$, then those in their second trimester $(523 \pm 41.3$ cells/ $\left.\mathrm{mm}^{3}\right)$. There was significant difference in the mean $\mathrm{CD}^{+}$ T-cell count of HIV-seropositive pregnant women based on the three gestational groups and $T$. gondii $\operatorname{IgM}(P=0.0048)$ and IgG status $(P<0.001)$ (Table 5$)$. Based on the T. gondii IgG serostatus, it was observed that HIV-seronegative pregnant women at their first trimester had the lowest mean $\mathrm{CD}^{+}$T-cell count $\left(562 \pm 67.2\right.$ cells $\left./ \mathrm{mm}^{3}\right)$, followed by those Https://dx.doi.org/10.4314/mmj.v32i3.9 
in their third trimester $\left(582 \pm 68.1\right.$ cells $\left./ \mathrm{mm}^{3}\right)$, then those in their second trimester $\left(611 \pm 72.9\right.$ cells $\left./ \mathrm{mm}^{3}\right)$. However, based on their T. gondii IgM serostatus, it was observed that HIV-seronegative pregnant women at their first trimester had the lowest mean CD4 ${ }^{+}$T-cell count $\left(426 \pm 0\right.$ cells $\left./ \mathrm{mm}^{3}\right)$, followed by those in their second trimester $(541 \pm 51.7$ cells $/$

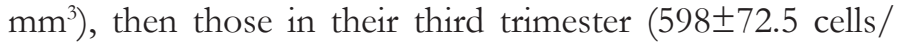
$\mathrm{mm}^{3}$ ). There was no significant difference in the mean $\mathrm{CD}^{+}$ T-cell count of HIV-seronegative pregnant women based on the three gestation groups and T. gondii $\operatorname{IgG}(P=0.27)$ and $\operatorname{IgM}$ status $(P=0.32)$ (Table 6$)$.

\section{Discussion}

In this study, the overall seroprevalence of anti- $T$. gondii (both IgG and IgM) among HIV-positive and HIV-negative pregnant women was found to be $33.8 \%$ and $31.2 \%$, respectively. There was a slight increase in seroprevalence of both IgG and IgM antibodies (29.4\% and 4.4\%) among the pregnant HIV-positive population over their HIV-negative counterparts $(28.1 \%$ and $3.1 \%)$. This difference could be due to the immunosuppression consequences in HIV-positive individuals which primarily manifests as a drop in their $\mathrm{CD}^{+}$ T-cell counts and function ${ }^{13}$.

Table 5. Comparison of $\mathrm{CD}^{+}{ }^{+} \mathrm{T}$-cell counts by gestation of $\mathrm{HIV}$-infected pregnant women with serological evidence of toxoplasmosis.

\begin{tabular}{|c|c|c|c|}
\hline \multicolumn{4}{|c|}{ ICD4 ${ }^{+}$T-cell count (cells $/ \mathrm{mm}^{3}$ ) mean \pm SD } \\
\hline HIV-seropositive & Anti-T. gondii lgG positive $(n=47)$ & HIV-seropositive & Anti-T. gondii IgM positive $(n=7)$ \\
\hline $\begin{array}{l}\text { 1st trimester ( } \mathrm{n} \\
=9 \text { ) }\end{array}$ & $358 \pm 28.6$ & $\begin{array}{l}\text { 1st trimester ( } \mathrm{n} \\
=1)\end{array}$ & $399 \pm 0$ \\
\hline $\begin{array}{l}\text { 2nd trimester ( } \mathrm{n} \\
=15)\end{array}$ & $323 \pm 24.2$ & $\begin{array}{l}\text { 2nd trimester ( } \mathrm{n} \\
=3 \text { ) }\end{array}$ & $523 \pm 41.3$ \\
\hline $\begin{array}{l}\text { 3rd trimester ( } \mathrm{n} \\
=23 \text { ) }\end{array}$ & $284 \pm 18.9$ & $\begin{array}{l}\text { 3rd trimester ( } \mathrm{n} \\
=3 \text { ) }\end{array}$ & $411 \pm 38.5$ \\
\hline $\mathrm{F}$ & 37.7689 & $\mathrm{~F}$ & 26.8822 \\
\hline$P$-value & $<0.0001^{*}$ & P-value & $0.0048^{*}$ \\
\hline
\end{tabular}

*Significant mean difference determined by one-way ANOVA

Tukey HSD post-hoc test for HIV-seropositive subjects with T. gondii IgG

1st trimester vs 2nd trimester: Diff. $=-35.0000 ; 95 \%$ confidence interval $(\mathrm{CI})=-58.1781$ to $-11.8219 ; P=0.0019$.

1st trimester vs 3rd trimester: Diff. $=-74.0000 ; 95 \% \mathrm{CI}=-95.6137$ to $-52.3863 ; P=0.0000$.

2nd trimester vs 3rd trimester: Diff. $=-39.0000 ; 95 \% \mathrm{CI}=-57.2440$ to $-20.7560 ; P=0.0000$.

Tukey HSD post-hoc test for HIV-seropositive subjects with T. gondii IgM

1st trimester vs 2nd trimester: Diff. $=124.0000 ; 95 \% \mathrm{CI}=-40.2969$ to $288.2969 ; P=0.11$.

1st trimester vs 3rd trimester: Diff. $=-115.0000 ; 95 \% \mathrm{CI}=-279.2969$ to $49.2969 ; P=0.14$.

2nd trimester vs 3rd trimester: Diff. $=-239.0000 ; 95 \% \mathrm{CI}=-355.1755$ to $-122.8245 ; P=0.003$.

Table 6. Comparison of $\mathrm{CD}^{+}$T-cell counts by gestation of $\mathrm{HIV}$-seronegative pregnant women with serological evidence of toxoplasmosis.

\begin{tabular}{|l|l|l|l|}
\hline \multicolumn{2}{|l|}{ CD4 ${ }^{+}$T-cell count $\left(\right.$cells $\left./ \mathbf{m m}^{3}\right)$ mean \pm SD } \\
\hline $\begin{array}{l}\text { HIV- } \\
\text { seronegative }\end{array}$ & Anti-T. gondii IgG positive $(\boldsymbol{n}=\mathbf{4 5})$ & $\begin{array}{l}\text { HIV- } \\
\text { seronegative }\end{array}$ & $\begin{array}{l}\text { Anti-T. gondii IgM } \\
\text { positive }(\boldsymbol{n}=\mathbf{5})\end{array}$ \\
\hline $\begin{array}{l}1 \text { st trimester } \\
(n=6)\end{array}$ & $562 \pm 67.2$ & $\begin{array}{l}\text { 1st trimester }(n \\
=1)\end{array}$ & $426 \pm 0$ \\
\hline $\begin{array}{l}\text { 2nd trimester } \\
(n=16)\end{array}$ & $611 \pm 72.9$ & $\begin{array}{l}\text { 2nd trimester }(n \\
=1)\end{array}$ & $541 \pm 51.7$ \\
\hline $\begin{array}{l}3 \text { rd trimester } \\
(n=23)\end{array}$ & $582 \pm 68.1$ & $\begin{array}{l}3 \text { rd trimester }(n \\
=3)\end{array}$ & $598 \pm 72.5$ \\
\hline$F$ & 1.3594 & $F$ & 2.1255 \\
\hline$P$-value & 0.2679 & $P$-value & 0.3199 \\
\hline
\end{tabular}

*Significant mean difference determined by one-way ANOVA. 


\section{Tukey HSD post-hoc test for HIV-seronegative subjects with T. gondii IgG}

1st trimester vs 2 nd trimester: Diff. $=49.0000 ; 95 \%$ confidence interval $(\mathrm{CI})=-32.1196$ to $130.1196 ; P=0.32$.

1st trimester vs 3rd trimester: Diff. $=20.0000 ; 95 \% \mathrm{CI}=-57.6800$ to $97.6800 ; P=0.81$.

2nd trimester vs 3rd trimester: Diff. $=-29.0000 ; 95 \% \mathrm{CI}=-84.1643$ to $26.1643 ; P=0.42$.

\section{Tukey HSD post-hoc test for HIV-seronegative subjects with $T$. gondii IgM}

1st trimester vs 2nd trimester: Diff. $=115.0000 ; 95 \% \mathrm{CI}=-488.9721$ to $718.9721 ; P=0.60$.

1st trimester vs 3rd trimester: Diff. $=172.0000 ; 95 \% \mathrm{CI}=-321.1412$ to $665.1412 ; P=0.30$.

2nd trimester vs 3rd trimester: Diff. $=57.0000 ; 95 \% \mathrm{CI}=-436.1412$ to $550.1412 ; P=0.80$.

The prevalence rates from this study are higher than the prevalence of $9.8 \%$ and $12.8 \%$ among an HIV-positive subgroup and HIV-negative pregnant women, respectively, reported in South Africa ${ }^{14}$. The overall seroprevalence in this study is in conformity with a previous seroprevalence of $31.5 \%$ recorded in the central city of Abuja ${ }^{8}$. The prevalence in this study was higher than the $29.9 \% 0^{3}$ recorded in Zaria but lower than others carried out in Lagos and Maiduguri where $40.2 \%$ and $48.9 \%$ were recorded, respectively ${ }^{10,15}$. The variations of findings from these studies could be due to differences in laboratory methods adopted by the studies, sample size, HIV and antiretroviral therapy statuses of study participants and endemicity of toxoplasmosis.

Lagos is a riverine area with a high prevalence of outdoor activities, whereas Maiduguri dwellers have been ravaged by national insecurity which grossly affected their standard of living and the socioeconomic status of residents, including access to potable water and hygienic meat and vegetables. Studies reported within and outside Africa have recorded seroprevalence rates among pregnant women of $83.6 \%$ in Ethiopia $^{16}, 92.5 \%$ in Ghana ${ }^{17}, 48.3 \%$ in India $^{18}$ and $56.6 \%$ in Brazil ${ }^{19}$. It is possible that geographical and hot climatic conditions in these countries that favour sporulation could account for these wide margins in prevalence ${ }^{20,21}$. The climatic condition in our study area may be relatively less favourable for the survival of oocysts compared with studies that reported a very high seroprevalence of toxoplasmosis. Prevalence rates as low as 10\% have been reported in the United States and the $\mathrm{UK}^{22,23}$. The lower rates found in developed countries are not surprising as these countries have higher standards of living, good potable water and proper waste disposal systems that might reduce the risk of contracting $T$. gondii infection.

The highest prevalence of $T$. gondii $\operatorname{IgG}$ and IgM antibodies was observed among women in the age group of 20-39 years. This was similar in both subgroups. Seroprevalence is said to increase with age among both immunocompromised and immunocompetent pregnant women ${ }^{8}$. This may be an indicator of susceptibility to $T$. gondii infection due to occupational hazards such as farming and contact with poultry in older populations, compared with younger populations who are less involved in these activities ${ }^{24}$. These findings corroborate the reports from Zaria in Nigeria ${ }^{25}$ and Saudi Arabia ${ }^{26}$.
Toxoplasmosis is a food-borne infection. IgG and IgM seropositivity were found to be higher among the urban dwellers than their rural counterparts in both the HIVpositive and HIV-negative pregnant women. This may be because urban dwellers are more likely to patronise fastfood vendors and restaurants with poor sanitary conditions. This action may predispose pregnant women, especially the 'working class', to consume poorly prepared vegetables and undercooked meat products from unprofessional vendors. A similar finding was reported by Nasir et al. ${ }^{15}$

There was a statistically significant relationship between attaining tertiary level of education among the HIV-negative pregnant women and a higher prevalence of $\operatorname{IgG}$ and $\operatorname{IgM}$ antibodies.

Although it is generally accepted that highly educated people are expected to know about infection prevention measures, we observed that this category of pregnant women might have contracted food-borne toxoplasmosis because their occupation might have affected their feeding habits, as previously explained. To further buttress this, urban residents had a higher prevalence of anti-T. gondii IgG than rural residents. However, this opposes other findings in studies that showed no significant association between different levels of education ${ }^{26,27}$.

The highest seroprevalence of anti- $T$. gondii $\operatorname{IgG}$ antibodies for both HIV-positive and HIV-negative pregnant women was found in the third trimester $(51.1 \%$ versus $48.9 \%)$ in this study. This could be due to the immunosuppressive effects of pregnancy at a late stage (third trimester) tending to predispose these women to higher chances of contracting $T$. gondii infection. It has been demonstrated that congenital transmission also increases with gestational age, with the highest rates in the third trimester ${ }^{11}$. On the other hand, disease severity has been reported to decrease with gestational age, with first-trimester infection resulting in miscarriage more often ${ }^{28}$.

The mean $\mathrm{CD}^{+}{ }^{+}$T-cell counts were found to be significantly lower in HIV-positive pregnant women with anti-T. gondii IgM antibodies compared with those with $\operatorname{IgM}$ seronegative results. Similar findings were also reported by Nazari et al. ${ }^{13}$ This might be due primarily to the synergistic effects of HIV infection and toxoplasmosis ${ }^{29}$.

In HIV infection, due to immunosuppression, opportunistic infection occurs with T. gondii because of depletion of CD4 
T cells, impaired production of IL-12 and interferon gamma $(\mathrm{IFN}-\gamma)$ and impaired cytotoxic T-lymphocyte activity ${ }^{29}$. There is decreased in vitro production of IL-12 and IFN- $\gamma$, and decreased expression of CD154 in response to T. gondii $i^{29}$. It could be inferred that the women with HIV infection should be considered at high risk for developing toxoplasmosis, especially when $\mathrm{CD}^{+}{ }^{+} \mathrm{T}$-cell count is very low. $\mathrm{CD} 4^{+} \mathrm{T}$-cell counts of less than 100 cells $/ \mathrm{mm}^{3}$ have been implicated in reactivation of latent infection which could lead to clinical neurologic disease. There are several toxoplasmosis crosssectional studies across different subpopulations. However, very few have focused on simultaneous investigation of toxoplasmosis and its impact on $\mathrm{CD}^{+} \mathrm{T}$ cellular immunity in pregnant women living with HIV/AIDS and those who were HIV seronegative. In this study, it was shown that primary toxoplasmosis in HIV infection significantly altered CD4 ${ }^{+}$ T-cell count of pregnant women. Hence, these findings will assist obstetricians and gynaecologists in the early diagnosis and management of T. gondii infection in pregnant women, especially HIV-coinfected individuals, to prevent intrauterine complications.

\section{Conclusion}

In this study, the seroprevalence of anti-T. gondii $\operatorname{IgG}$ and $\operatorname{IgM}$ did not differ in the HIV-seropositive or HIV-seronegative pregnant population. However, women with primary $T$. gondii and HIV coinfection had lower $\mathrm{CD}^{+} \mathrm{T}$-cell count than those with toxoplasmosis monoinfection.

Place of residence and level of education among HIVnegative pregnant women have significant association with toxoplasmosis. There is a need to educate pregnant women about preventive strategies and risk factors that could predispose them to $T$. gondii infection and to prevent consequential congenital infections.

\section{Authors' contributions}

Conceptualisation and design of paper: MMZ, AYI.

Collection of data: MMZ, AYI, RO, TY, INA.

Implementation of research: MMZ, AYI, RO, TY, INA.

Data analysis and interpretation: MMZ, AYI, INA.

Preparation of manuscript: MMZ, AYI, RO, TY, INA.

All authors checked and approved the final manuscript before submission.

\section{Competing interests}

None to declare.

\section{References}

1. Rostami A, Riahi SM, Gamble HR, Fakhri Y, Nourollahpour Shiadeh M, Danesh M, et al. Global prevalence of latent toxoplasmosis in pregnant women: a systematic review and meta-analysis. Clin Microbiol Infect. 2020;26(6):673-83. doi: 10.1016/j.cmi.2020.01.008.

2. Ayi I, Sowah AO, Blay EA, Suzuki T, Ohta N, Ayeh-Kumi PF. Toxoplasma gondii infections among pregnant women, children and HIV seropositive persons in Accra, Ghana. Trop Med Health. 2016;44:17. doi: https://doi.org/10.1186/s41182-016-0018-5.

3. Mendez OA, Koshy AA. Toxoplasma gondii: entry, association, and physiological influence on the central nervous system. PLoS Pathog. 2017;13(7):e1006351. doi: https://doi.org/10.1371/journal. ppat. 1006351

4. Rezanezhad H, Sayadi F, Shadmand E, Nasab SDM, Yazdi HR, Solhjoo K, et al. Seroprevalence of Toxoplasma gondii among HIV Patients in Jahrom, Southern Iran. Korean J Parasitol. 2017;55:99-103. doi: https://doi.org/10.3347/kjp.2017.55.1.99.

5. Machala L, Malý M, Hrdá S, Rozsypal H, Stanková M, Kodym P. Antibody response of HIV-infected patients to latent, cerebral and recently acquired toxoplasmosis. Eur J Clin Microbiol Infect Dis. 2009;28:179-82. doi: https://doi.org/10.1007/s10096-008-0600-9.

6. Katawa G, Kolou M, Nadjir LK, Ataba E, Bomboma G, Karou SD. CD4 T-lymphocytes count in HIV-Toxoplasma gondii coinfected pregnant women undergoing a prevention of mother-to-child transmission program. J Biosci Med. 2018;6:76-84. doi: https://doi. org/10.4236/jbm.2018.64006.

7. Nigerian National AIDS Indicator and Impact Survey. Press Release. 2019 [cited 2020 Apr 21]. Available from: https://www.unaids.org/ en/resources/presscentre/pressreleaseandstatementarchive/2019/ march/20190314_nigeria.

8. Uttah EC, Ajang R, Ogbeche J, Etta H, Etim L. Comparative seroprevalence and risk factors of toxoplasmosis among three subgroups in Nigeria. J. Nat Sci Res. 2013;3(8):23-9. Available from: https://www. iiste.org/Journals/index.php/JNSR/article/view/6891/6997.

9. Ishaku BS, Ajogi I, Umoh UJ, Lawal I, Randawa AJ. Seroprevalence and risk factors for Toxoplasma gondii infection among antenatal women in Zaria, Nigeria. Res J Med Sci 2009;4(2):483-8. doi: https:// doi.org/10.9734/AJMAH/2017/31528.

10. Deji-Agboola AM, Busari OS, Osinupebi OA, Amoo AOJ. Seroprevalence of Toxoplasma gondii antibodies among pregnant women attending antenatal clinic of Federal Medical Centre Lagos, Nigeria. Int J Biol Med Res. 2011;2(4):1135-9.

11. Thiebaut R, Leproust S, Chene G, Gilbert R. Effectiveness of prenatal treatment for congenital toxoplasmosis: a meta-analysis of individual patient's data. Lancet. 2007;369(9556):115-22. doi: https:// doi.org/10.1016/S0140-6736(07)60072-5.

12. Declaration of Helsinki 2000. World Medical Association [cited 2020 Apr 29]. Available from: https://www.wma.net/what-we-do/ medical-ethics/declaration-of-helsinki/doh-oct2000/.

13. Nazari N, Bozorgomid A, Janbakhsh A, Bashiri F. Toxoplasma gondii and human immunodeficiency virus co-infection in western Iran: a cross sectional study. Asian Pac J Trop Med. 2018;11:58-62. doi: https://doi.org/10.4103/1995-7645.223562.

14. Kistiah K, Barragan A, Winiecka-Krusnell J, Karstaedt A, Frean J. Seroprevalence of Toxoplasma gondii infection in HIV positive and HIV negative subjects in Gauteng, South Africa. South Afr J Epidemiol Infect. 2011;26(4):225-8. doi: https://doi.org/10.1080/10158782.2011. 11441457.

15. Nasir IA, Aderinsayo AH, Mele HU, Aliyu MM. Prevalence and associated risk factors of Toxoplasma gondii antibodies among pregnant women attending Maiduguri Teaching Hospital, Nigeria. J Med Sci. 2015;15(3):147-54. doi: https://doi.org/jms.2015.147.154.

16. Zemene E, Yewhalaw D, Abera S, Belay T, Samuel A, Zeynudin A. Seroprevalence of Toxoplasma gondii and associated risk factors among pregnant women in Jimma town, Southwestern Ethiopia. BMC Infect Dis. 2012;12:337. doi: https://doi.org/10.1186/1471-2334-12-337.

17. Ayi I, Edu A, Apea-Kubi K, Boamah D, Bosompem K, Edoh D. Sero-epidemiology of toxoplasmosis amongst pregnant women in the Greater Accra Region of Ghana. Ghana Med J. 2009;43:107-14. doi: https://doi.org/10.4314/gmj.v43i3.55325.

18. Singh S, Pandit AJ. Incidence and prevalence of toxoplasmosis in Indian pregnant women: a prospective study. Am J Reprod Immunol. 2004;52:276-83. doi: https://doi.org/10.1111/j.16000897.2004.00222.x

19. Vaz RS, Thomaz-Soccol V, Sumikawa E, Guimaraes ATB. Seroprevalence of Toxoplasma gondii antibodies in pregnant women in southern Brazil. Parasitol Res. 2010;106:661-5. doi: https://doi. org/10.1007/s00436-009-1716-2.

20. Nijem KI, Al-Amleh S. Seroprevalence and associated risk factors of toxoplasmosis in pregnant women in Hebron district, Palestine. East Mediterr Health J. 2009;15:1278-84. Available from: http://applications. emro.who.int/emhj/1505/15_5_2009_1278_1284.pdf. 
21. Tenter AM, Heckeroth AR, Weiss LM. Toxoplasma gondii: from animals to humans. Int J Parasitol. 2000;30(12-13):1217-58. doi: https://doi.org/10.1016/s0020-7519(00)00124-7.

22. Jones JL, Kruszon-Moran D, Sanders-Lewis K, Wilson M. Toxoplasma gondii in the United States, 1999-2004, decline from the prior decade. Am J Trop Med Hyg. 2007;77(3):405-10.

23. Nash JQ, Chissel S, Jones J, Warburton F, Verlander NQ. Risk factors for toxoplasmosis in pregnant women in Kent, United Kingdom. Epidemiol Infect. 2005;133(3):475-83. doi: https://doi.org/10.1017/ s0950268804003620.

24. Aqeely H, El-Gayar EK, Khan DP, Najmi A, Alvi A. Seroepidemiology of Toxoplasma gondii amongst pregnant women in Jaza province, Saudi Arabia. J Trop Med. 2014;2014:913950. doi: https://doi.org/10.1155/2014/913950.

25. Ogoina D, Onyemelukwe GC, Musa BO, Obiako RO. Seroprevalence of $\operatorname{IgM}$ and $\operatorname{IgG}$ antibodies to Toxoplasma infection in healthy and HIV positive adults from northern Nigeria. J Infect Dev Countr. 2013;7(5):398-403. doi: https://doi.org/10.3855/jidc.2797.

26. Al- Harthi AS, Menal H, Ghazi HO. Seroprevalence of Toxoplasma gondii among pregnant women in Makkah, Saudi Arabia. Um Al Qura Univ J Sci Med Eng. 2006;8(2):217-27.

27. Gelaye W, Kebede T, Hailu A. High prevalence of anti-Toxoplasma antibodies and absence of Toxoplasma gondii infection risk factors among pregnant women attending routine antenatal care in two hospitals of Addis Ababa, Ethiopia. Int J Infect Dis. 2015;34:41-5. doi: https://doi.org/10.1016/j.jiid.2015.03.005.

28. Ghasemi FS, Rasti S, Piroozmand A, Bandehpour M, Kazemi B, Mousavi SG, et al. Toxoplasmosis-associated abortion and still birth in Tehran, Iran. J Matern Fetal Neonatal Med. 2016;(2):248-51. doi: https://doi.org/10.3109/14767058.2014.996127.

29. Basavaraju A. Toxoplasmosis in HIV infection: an overview. Trop Parasitol. 2016;6(2):129-35. 